\title{
Child Maltreatment as Predictors of Criminal Thinking Styles among Adolescents
}

\author{
Malek Y. Alkhutaba*, Zahria I. Abdihaq \\ Department of Psychology, Isra University, Amman, Jordan \\ Email: *dr_malek78@hotmail.com
}

How to cite this paper: Alkhutaba, M.Y. and Abdihaq, Z.I. (2018) Child Maltreatment as Predictors of Criminal Thinking Styles among Adolescents. Open Journal of Social Sciences, 6, 1-14. https://doi.org/10.4236/jss.2018.611001

Received: September 4, 2018

Accepted: November 3, 2018

Published: November 6, 2018

Copyright (๑) 2018 by authors and Scientific Research Publishing Inc. This work is licensed under the Creative Commons Attribution International License (CC BY 4.0).

http://creativecommons.org/licenses/by/4.0/

(c) (i) Open Access

\begin{abstract}
The purpose of this study was to examine the child maltreatment as predictors of criminal thinking style among Adolescents. Sample of the study consisted of 150 adolescents (75 Juveniles and 75 normal people) were compared regarding to study variables, the participants almost all existing socioeconomic classes such as low, middle, and high classes in Jordan and they are similar in age, ranging from 12 to 18 years. They are also homogenous about nationality. Moreover, the sample was selected from public schools and rehabilitation centers for juveniles in Russeifa city in Jordan. For data collection, child maltreatment scale and criminal thinking styles "PICTS" which are founded by Imad Mikhmer, 2000 and Glenn Walters, 1989 respectively have been used. Results of the study indicated that there are statistically significant differences at $\alpha \leq 0.05$ between juveniles and normal people regarding the variables of the study in favor of criminal's participants. While, there are no significant influence in mother physical maltreatment among the participants. Also, results of the study find out that there is a statistically significant relationship at $\alpha \leq 0.05$ between child maltreatment and criminal thinking styles. Finally, results of the study presented that the criminal thinking can be predicted from perceived father and mother maltreatment in childhood. Results show the danger of child maltreatment and how it affects in future and security of society, and how the cycle of maltreatment works with victim being prone to become a juvenile in the future.
\end{abstract}

\section{Keywords}

Child Maltreatment, Criminal Thinking Styles and Adolescents

\section{Introduction}

Child maltreatment is one of the most serious problems can result from emo- 
tional, sexual and physical harm which is facing human societies nowadays, which is resulting devastating effects on individuals and societies such as spreading anxiety and insecure feeling. As society progresses and develops [1], this problem is exacerbated and become more complex in societies structure leading to widespread effects. The reasons and motives of committing child maltreatment are many and vary, which eventually lead to criminal behavior. Waltres, 2007 posits that the individual's lifestyle may be pushes him in criminal behavior, also the social and cognitive perceptions regarding conditions interact together and promote a criminal thinking. While, Widom 1989 indicated that the more experiences in childhood abuse increase the probability of predicting criminal behavior in the future and the abuse of the individual lead to a sense of insecurity and low value which increases aggression desire [2].

Early childhood is the most important and influential life phase in personality, configure the psychological and social schemes through the interaction of experiences gained, as any disorder in the early growth process often leading to disorder in subsequent process of growth and development stages, and the extent of individual early growth process success shows in adulthood phase through his ability to deal and cope the life requirements [3].

In the past, child save has been commonly perceived to be a matter of concern to psychologist and sociologist service, health, mental health, and justice systems. The phenomenon of childcare began in 1920s, and the first laws for child rights were declare in 1923, also the general assembly of the united nation has been adopted the international declaration of child rights in 1959 [4]. While, the convention on the rights of the child have been issued in 1989 which is undertakes to protect and promote the child rights and support the child growth and development, the article 19 from convention on the rights of the child involving protect the child from all forms of or mental or physical violence, abuse or injury, neglect or negligent treatment, maltreatment or exploitation, including sexual abuse, while in the care of parent, legal guardians or any other person who has the care of the child [5].

\section{The Study Problem}

Child maltreatment phenomenon is an international subject with earnest lifelong outcome with different causes considered as predicting factor for criminal behavior, addiction, psychological and mental disorders. While, the dangerous of this issue lies in its prevalence rate and Implications, also appears in absence of accurate statistics to be counted. Child maltreatment has many causes, some internal related to individuals and others external related to environment, there for the ways of reform or punishment not enough to cope this important issue, many dangers factors for child maltreatment have been explained. These dangers factors are not existing in all cultural and social conditions but present an overview when trying to understand the child maltreatment causes. There is a relationship between child maltreatment and adolescent's behaviors, because the 
maltreatment experiences in childhood is one of psychological factor that affect in individual mental health, these experiences represent a predicting factor in criminal and disorder behavior which is maybe leads to some psychological disorders among adolescents, the current research trying to examine the relationship between child maltreatment and criminal thinking styles among adolescents.

\subsection{Objectives of the Study}

This study aims to:

1) Know the relationship between child maltreatment and criminal thinking styles among adolescents.

2) Know whether the child maltreatment is predictors of criminal thinking style among adolescents.

\subsection{Questions of the Study}

1) Is there a statistically significant relationship between child maltreatment and criminal thinking styles among adolescents?

2) Do criminal thinking style predictors of child maltreatment among adolescents?

\subsection{The Study Concepts}

1) Child maltreatment: Physical, emotional, sexual, and ignoring intentionally or unintentionally act affect in development and growth of children's.

2) Criminal thinking styles: it's the cognitive activities that characterize the criminals thinking or who are at risk of being involved in criminal behavior, consisting the mollification, cutoff, entitlement, power-orientation, sentimentality, super-optimism, cognitive indolence, and discontinuity.

\subsection{Concept of Child Maltreatment}

Child maltreatment has far-reaching effects, violence, for example, can lead to stress that damages both development as well as the nervous and immune system. This of course results in delayed cognitive development; poor school performance drops out mental health problems suicide attempts as well as increased health-risk behaviors [6]. Surprisingly enough is that interventions through support parent and caregivers can prevent maltreatment and promote non-violent attitudes and values, provide education and life skills training, increase families' income and economic security, create safe environment for children and finally, reinforce laws against the so-called child maltreatment [7].

International association for protection of children from abuse and neglect has been defined the child maltreatment as any act of violence or neglect recognized by a parent or caregiver resulting in imminent danger such as physical, emotional, or sexual abuse. United States department of health and human services 1981 also defined the child maltreatment as physical, sexual, and neglect or 
bad-deals of children who are under 18 years by a person who is responsible of health and child well-being in conditions where the child's health and well-being expose to harm or threat [8].

Angry or violent attack in words, bad language and cursing that occur to children under 18 years of age are examples of the abuse according to world health organization. The types of child maltreatment also include all types of physical, sexual, and emotional or neglect. These results in actual harm to the child's development, survival health to dignity in the form of a relationship of responsibility, trust or power what is more exposing a child to the so-called intimate partner violence is another form of child maltreatment [9]. There are many factors commonly affects in child maltreatment, family, social conditions, and environments have a greater influence of experiencing maltreatment, where the family is the basis in socialization building of children. However, the conditions that experienced by many families such as poverty, unemployment, social equivalence, structure of family, attitudes of parental, parental violence, low socioeconomic status, non-biological adult living in the home, and approaches of childrearing that contributed and negatively affects in socialization building and place the children at maltreatment risk [10].

\subsection{Types of Child Maltreatment}

The types of child maltreatment have been varied, in the past known as traditional type such as infanticide, murder, torture. While nowadays the child maltreatment known as begging, working in factories and foundations. World health organization distinguishes four types of child maltreatment differs in symptoms and severity represented in [11]:

1) Physical maltreatment: using the force against the children with intent of harming and causing hurt to him, this diagnostic type use when the center of clinical attention is a body abuse of children, including the body wounds caused by parents beating or any other person to the children either by hand, foot, hair tightening, biting, strangulation, and burning or anybody torture in different forms resulting infection varying in severity.

2) Emotional maltreatment: this diagnostic use when the center of clinical attention is the emotional abuse of children, involve deliberately trying to scare or humiliate a child or isolating or ignoring them.

3) Sexual maltreatment: in this matter, the central of clinical attention is sexual abuse of children, known as unwanted sexual child experience constitutes a deception, violation and rest of child innocence, getting between touch and un-touch abuse such as showing sexual pictures or viewing sexual movies or positions, having sex with a child, and sexual harassment.

4) Neglect: filing to provide a child with the needed food, clothing, shelter, medical care as well as supervision can lead to what is known as neglect. This of course threatens the child's health, safety as well as his well-being. I go without saying that neglect also results from a lack of attention love, nurture, the 
non-provision of sufficient necessities for a child's survival on the part of the people around him. To sum up, the lack of things threatens the child with harm [12].

Childhood maltreatment is a complex matter in the light of multiple cultural, personal, social, and other factors. There are many theories and models that explain this phenomenon. On the other hand, there is no any single theory can explain all the aspects surrounding the child maltreatment, there are a several theories drives the psychologist methods for child maltreatment. According to environment theory as basically posited by Grabrino, 1988. The social environment, including parents and many factors that enable the guardian to be abusive, also Grabrino says that there are two factors contributing to use violence against children, 1) cultural justification for using force in behaving a child, 2) the family system, which is receive the social systems support such as neighbors, school, and society [13].

Belsky, 1984 indicates to the structural levels analysis where the first level according his opinion is growth of individual, experiences of parents, and methods of rearing of children, the second level is the internal family system which is responsible the children care and protection this evident when there are obstacles in family system, where the external system such as friends neighbors did not directly affect the individual but contribute to his harm, the fourth level is cultural heritage, beliefs system, and culture prevalent in society is promoted the abuse. where the ecosystem in which the individual lives has profound effect of hurting the child. child can have abused by poverty, unemployment, or loss of his or her father's job, result of this frustration and stress increases [14].

Bandura in his theory about the social learning posit that the individual learned the behavior during rewarding for action or by meditation of the other behaviors [15]. On the base of this posit individual learn to be naughty during style of meditation and carry on the behavior into puberty. This aggression model is generally indicated to as the violence cycle which is assumption that a childhood experience of physical maltreatment predisposes the individual to violence in adolescent's years [10].

\section{Literature Review}

The research and literature on child maltreatment presents many suggests about the results of child maltreatment for the victim, family, and society. Abuse and neglect can lead to serious and constant mental, physical, and emotional disorders, as well as in future criminal behavior. Some studies have been conducted in child maltreatment presented a relationship between childhood experiences and adult disorders and negative health behaviors. McGrath (2011) studied the relationship between sexual abuse during childhood and subsequent criminal thinking, Texas Christian University Criminal Thinking Scales (TCUCTS) have been used as a tool of the study. Results of the study indicated that the exposure to sexual abuse during childhood plays an important role in level of criminal 
thinking, moreover the repetition of abuse, duration, and the relation between the aggressor and victim also plays an important role in level of criminal thinking and commission of deviant behavior. The severity of perverse behavior and criminal thinking increases whenever the sexual abuse increases during childhood [16].

Study of Walters, 2010 detected the factors of child abuse that cause criminal thinking in juvenile delinquents, the study finds out that the methods of severe, cruel discipline, poverty, neglect, and parental rejection are factors that have a significant impact on juvenile delinquency and patterns of criminal thinking [17]. Also, Zurbriggen and Gobin, 2009 in his research about exposure to experiences of emotional abuse and its relationship to committing sexual crimes and criminal thinking presented a predictability of sexual offenses against women and their aggressive behavior towards men in adolescence due to emotional abuse in childhood. The results also indicated a higher level of criminal thinking of those who were more emotionally abused than others [18]. Cuadra, Anna, Renu \& DiLillo, 2014 examine the relationship between abuse experiences during childhood and criminal behavior in adulthood and its association with criminal thinking patterns, the results showed that child abuse in general was positively associated with criminal behavior [19].

\section{Study Sample}

The researcher has been employed a descriptive correlation design. A total sample was 150 participants (75 criminals and 75 normal participants) the sample that available to the researcher were selected, the participants almost all existing socioeconomic classes such as low, middle, and high classes in Jordan and they are similar in age, ranging from 12 to 18 years. They are also homogenous about nationality. Moreover, the normal participants were selected from public schools and the Juveniles participants were selected from correction and rehabilitation center for juvenile in Russeifa city in Jordan.

\section{Measures}

Experienced chilmal treaetment scale development by Imad Mikhmer \& Imad Abd-Elrazaq, 2000. The scale aims to obtain estimate quantitative for physical, sexual, and emotional maltreatment or neglect that has been experienced in childhood. the scale consists two models (father and mother models) where every model involving of 32 Items all formed in the negative direction, also the scale contains four alternative options; responders are required to select one of them scored as always $=4$, often $=3$, rarely $=2$ and never $=1$.

While the second tool was criminal thinking styles inventory "PICTS" standardized by Walters, 1989. This scale consists 80 items involving 8 criminal thinking styles contains four alternative options scored as: strongly agree $=4$, agree $=3$, not certain $=2$, and not agree $=1$, related to items number 6, 16, 20, and 59 the examinee must be given opposite score. Professors of English litera- 
ture fluent in English and Arabic have translated the instruments from English to Arabic language. Their comments suggestions were incorporated of terms that the items conveying the same meaning, easy to understand.

\section{Validity and Reliability}

First, observed validity: scales were presented to professors and professionals in psychology and sociology to check the items suitability to measure the study aims, their comments and suggestions were incorporated of terms that easy to understand, open to one interpretation, and stabile to nature of the study.

Second, test-retest as means of achieving coefficient reliability Alpha Cronbach has been calculated. The test was administered to 25 criminal participants and 25 normal participants twice with interval of 14 days. The results showed that the total internal consistency of chilmal treaetment and criminal thinking style inventories are $0.89 \& 0.73$ respectively, which is within the acceptable range of internal consistency for a study.

\section{Procedures of the Study}

After taken no objection letter from proposed responsible party, participants were invited to participant in the study, and after brief introduction about the study, objectives of the study were explained to them, they were informed that results would be kept strictly confidential and efforts were made to get their maximum cooperation tabular presentation of sample, the scales were applied individually and time taken by each participant varies 40 to 60 minutes.

The researcher employed the SPSS Statistical Package for Social Sciences to conduct a micro or simple analysis of the quantitative data obtained from the respondents. Statistical techniques in accordance with the various objectives of the study will be used to test the hypotheses based on the objectives. Descriptive techniques such as: Pearson correlation coefficient, $t$-test, variance analysis, and stepwise regression analysis.

\section{Results of the Study}

First question, Is there a statistically significant relationship between child maltreatment and criminal thinking styles among adolescents?

To answer the question, $\mathrm{t}$-test have been calculated and presented in below tables.

Table 1 presented that there are statistically significant at $\alpha \leq 0.05$ in child maltreatment (father. mother, and sexual maltreatment) between the participant in favor of criminal's participants. While, the results find out a significant difference between the participants in emotional mother maltreatment in favor of non-criminal's participants.

Table 2 presented that there are statistically significant at $\alpha \leq 0.05$ in criminal thinking style between the participants in favor of criminals.

Second question. Do child maltreatment predictors of criminal thinking style 
Table 1. $t$-test results presents the differences on child maltreatment between the participants.

\begin{tabular}{ccccccc}
\hline \multirow{2}{*}{ Child maltreatment } & \multicolumn{3}{c}{ Criminal participants } & \multicolumn{2}{c}{ Normal participants } & \multirow{2}{*}{$\mathbf{t}$} \\
\cline { 3 - 6 } & Mean & Standard deviation & Mean & Standard deviation & \\
\hline \multirow{2}{*}{ Father } & Physical & 23.03 & 9.27 & 18.20 & 2.61 & $5.09^{*}$ \\
Model & Emotional & 24.72 & 10.66 & 23.43 & 3.59 & 1.17 \\
& Total score & 47.76 & 19.37 & 41.63 & 4.62 & $3.11^{*}$ \\
& Physical & 18.30 & 5.48 & 17.82 & 2.60 & 0.82 \\
Mother & Emotional & 21.38 & 6.78 & 19.28 & 3.60 & $5.38^{*}$ \\
Model & Total score & 39.68 & 11.95 & 37.10 & 5.05 & $2.06^{*}$ \\
& & & & & & \\
Sexual maltreatment & 13.09 & 3.55 & 11.071 & 1.05 & $3.73^{*}$ \\
\hline
\end{tabular}

*significant at $\alpha \leq 0.05$.

Table 2. $\mathrm{t}$-test results shows the differences on criminal thinking style between participants.

\begin{tabular}{cccccc}
\hline \multirow{2}{*}{ Dimensions } & \multicolumn{2}{c}{ Criminal participants } & \multicolumn{2}{c}{ Normal participants } & \multirow{2}{*}{ t } \\
\cline { 2 - 5 } & Mean & Standard deviation & Mean & Standard deviation & \\
\hline Mollification & 50.55 & 0.88 & 49.11 & 0.23 & $15.92^{*}$ \\
Cutoff & 50.52 & 0.90 & 49.16 & 0.38 & $14.19^{*}$ \\
Entitlement & 50.48 & 0.97 & 49.23 & 0.37 & $12.29^{*}$ \\
Power-orientation & 50.31 & 1.07 & 49.50 & 0.60 & $6.98^{*}$ \\
Sentimentality & 50.59 & 0.81 & 49.04 & 0.27 & $18.28^{*}$ \\
Super-optimism & 50.53 & 0.89 & 49.13 & 0.33 & $15.03^{*}$ \\
Cognitive indolence & 50.26 & 1.11 & 49.58 & 0.57 & $5.69^{*}$ \\
Discontinuity & 50.31 & 1.07 & 49.49 & 0.58 & $7.06^{*}$ \\
\hline
\end{tabular}

*significant at $\alpha \leq 0.05$.

among adolescents? To answer the question, Person correlation coefficient and stepwise regression analysis have been calculated and presented in below Table 3.

Results in Table 3 presented positive correlation relationship between father maltreatment and dimension of criminal thinking style, also there are positive correlation relationship between mother maltreatment, entitlement, and super-optimism dimension.

Table 4 indicated a positive correlation relationship between father maltreatment and super-optimism dimension, while results found out a positive correlation relationship between mother maltreatment, super-optimism, and cognitive indolence. Finally, a positive correlation relationship between sexual maltreatment, mollification, and entitlement. 
Table 3. Presents results of Person correlation coefficient among criminals' participant.

\begin{tabular}{|c|c|c|c|c|c|c|c|c|c|}
\hline \multicolumn{2}{|c|}{ Child maltreatment } & \multirow{2}{*}{$\begin{array}{c}\text { Mollification } \\
0.18^{*}\end{array}$} & \multirow{2}{*}{$\begin{array}{c}\text { Cutoff } \\
0.35^{\star}\end{array}$} & \multirow{2}{*}{$\begin{array}{c}\text { entitlement } \\
0.17^{\star}\end{array}$} & \multirow{2}{*}{$\begin{array}{c}\text { power-orientation } \\
0.32^{\star}\end{array}$} & \multirow{2}{*}{$\begin{array}{c}\text { sentimentality } \\
0.19^{\star}\end{array}$} & \multirow{2}{*}{$\begin{array}{c}\text { super-optimism } \\
0.34^{\star}\end{array}$} & \multirow{2}{*}{$\begin{array}{c}\begin{array}{c}\text { cognitive } \\
\text { indolence }\end{array} \\
0.28^{*}\end{array}$} & \multirow{2}{*}{$\begin{array}{c}\text { discontinuity } \\
0.30^{*}\end{array}$} \\
\hline \multirow{3}{*}{$\begin{array}{l}\text { Father } \\
\text { Model }\end{array}$} & Physical & & & & & & & & \\
\hline & Emotional & $0.32^{*}$ & $0.39^{*}$ & $0.25^{*}$ & $0.39^{*}$ & $0.30^{*}$ & $0.34^{*}$ & $0.34^{*}$ & $0.38^{*}$ \\
\hline & Total & $0.27^{\star}$ & $0.38^{\star}$ & $0.22^{\star}$ & $0.37^{*}$ & $0.26^{*}$ & $0.35^{*}$ & $0.32^{*}$ & $0.35^{\star}$ \\
\hline \multirow{3}{*}{$\begin{array}{l}\text { Mother } \\
\text { Model }\end{array}$} & Physical & $0.17^{\star}$ & 0.12 & $0.16^{*}$ & $0.27^{\star}$ & 0.10 & 0.13 & 0.07 & $0.27^{*}$ \\
\hline & Emotional & $0.26^{*}$ & $0.17^{*}$ & $0.22^{*}$ & $0.38^{*}$ & $0.16^{*}$ & 0.20 & $0.16^{*}$ & $0.39^{*}$ \\
\hline & Total & $0.22^{*}$ & 0.15 & $0.20^{*}$ & $0.34^{*}$ & 0.14 & $0.17^{*}$ & 0.12 & $0.34^{*}$ \\
\hline \multicolumn{2}{|c|}{ Sexual maltreatment } & $0.41^{*}$ & $0.16^{*}$ & $0.33^{*}$ & $0.28^{*}$ & $0.27^{* *}$ & $0.30^{*}$ & $0.17^{*}$ & $0.31^{*}$ \\
\hline
\end{tabular}

* significant at $\alpha \leq 0.05$.

Table 4. Presents results of person correlation coefficient among non-criminal's participants.

\begin{tabular}{|c|c|c|c|c|c|c|c|c|c|}
\hline \multicolumn{2}{|c|}{ Child maltreatment } & \multirow{2}{*}{$\begin{array}{c}\text { Mollification } \\
0.21^{\star}\end{array}$} & \multirow{2}{*}{$\begin{array}{c}\text { Cutoff } \\
0.27^{\star}\end{array}$} & \multirow{2}{*}{$\begin{array}{c}\text { entitlement } \\
0.33^{*}\end{array}$} & \multirow{2}{*}{$\begin{array}{c}\text { power-orientation } \\
0.45^{\star}\end{array}$} & \multirow{2}{*}{$\begin{array}{c}\text { sentimentality } \\
0.10\end{array}$} & \multirow{2}{*}{$\begin{array}{c}\text { super-optimism } \\
0.31^{\star}\end{array}$} & \multirow{2}{*}{$\begin{array}{c}\begin{array}{c}\text { cognitive } \\
\text { indolence }\end{array} \\
0.10\end{array}$} & \multirow{2}{*}{$\begin{array}{c}\text { discontinuity } \\
0.14\end{array}$} \\
\hline \multirow{3}{*}{$\begin{array}{l}\text { Father } \\
\text { Model }\end{array}$} & Physical & & & & & & & & \\
\hline & Emotional & $0.20^{*}$ & 0.02 & 0.18 & 0.14 & 0.08 & 0.06 & -0.10 & $0.34^{*}$ \\
\hline & Total & $0.28^{*}$ & 0.17 & $0.32^{*}$ & $0.36^{*}$ & 0.12 & $0.22^{*}$ & -0.02 & $0.34^{*}$ \\
\hline \multirow{3}{*}{$\begin{array}{l}\text { Mother } \\
\text { Model }\end{array}$} & Physical & 0.14 & $0.21^{\star}$ & 0.16 & $0.29^{*}$ & 0.12 & $0.27^{*}$ & 0.14 & 0.08 \\
\hline & Emotional & $0.36^{*}$ & 0.16 & $0.37^{*}$ & $0.30^{*}$ & 0.06 & 0.17 & 0.17 & $0.39^{*}$ \\
\hline & Total & $0.33^{*}$ & $0.22^{*}$ & $0.35^{*}$ & $0.36^{*}$ & 0.11 & $0.26^{*}$ & $0.20^{*}$ & $0.32^{*}$ \\
\hline \multicolumn{2}{|c|}{ Sexual maltreatment } & $0.28^{*}$ & 0.08 & $0.29^{*}$ & 0.17 & 0.10 & 0.05 & -0.01 & 0.16 \\
\hline
\end{tabular}

*significant at $\alpha \leq 0.05$.

Table 5 presented that the results of analysis of variance were statistically significant, which indicating to possibility of applying the stepwise regression analysis to find out the effect of independent variable in dependent variable.

The results in Table 6 indicated that:

1) The sexual maltreatment, emotional and physical maltreatment of father can be predicted in mollification pattern in criminal thinking with contribution percentage $17 \%, 20 \%$, and $23 \%$ respectively, this result can be formulated as a predictive equation in:

Mollification $=0.31 \times$ Sexual maltreatment $+0.57 \times$ emotional maltreatment of father $-0.43 \times$ Physical maltreatment of father +49.42 .

2) The emotional maltreatment of father can be predicted in cutoff pattern in criminal thinking with contribution percentage $23 \%$, the predictive equation can be formulated as:

Cutoff pattern $=0.15 \times$ emotional maltreatment of father +49.69 .

3) The sexual maltreatment can be predicted in cutoff pattern in criminal thinking with contribution percentage $11 \%$, the predictive equation can be formulated as:

Entitlement pattern $=0.33 \times$ sexual maltreatment 49.42 . 
Table 5. Shows results of variance analysis for independent variable "child maltreatment" in dependent variable "criminal thinking style.

\begin{tabular}{|c|c|c|c|c|c|c|}
\hline Dimension & Maltreatment & Model & $\begin{array}{l}\text { Sum of } \\
\text { squares }\end{array}$ & df & $\begin{array}{l}\text { Mean of } \\
\text { squares }\end{array}$ & f \\
\hline \multirow{3}{*}{ Mollification } & \multirow{3}{*}{$\begin{array}{l}\text { Sexual, Emotional, } \\
\text { Physical of } \\
\text { father maltreatment }\end{array}$} & Regression & 29.74 & 3 & 9.91 & \\
\hline & & Residuals & 98.03 & 259 & 0.62 & $16.08^{*}$ \\
\hline & & Total & 127.77 & 162 & & \\
\hline \multirow{3}{*}{ Cutoff } & \multirow{3}{*}{$\begin{array}{l}\text { Emotional of } \\
\text { father maltreatment }\end{array}$} & Regression & 20.32 & 1 & 20.32 & \\
\hline & & Residuals & 113.16 & 161 & 0.70 & $28.90^{*}$ \\
\hline & & Total & 133.47 & 162 & & \\
\hline \multirow{3}{*}{ Entitlement } & \multirow{3}{*}{ Sexual maltreatment } & Regression & 16.52 & 1 & 16.52 & \\
\hline & & Residuals & 135.61 & 161 & 0.84 & $19.61^{*}$ \\
\hline & & Total & 152.12 & 162 & & \\
\hline \multirow{3}{*}{ Power-orientation } & \multirow{3}{*}{$\begin{array}{c}\text { Sexual, Emotional, } \\
\text { Physical maltreatment } \\
\text { of mother }\end{array}$} & Regression & 39.55 & 3 & 13.18 & \\
\hline & & Residuals & 145.43 & 159 & 0.92 & $14.41^{*}$ \\
\hline & & Total & 184.9 & 162 & & \\
\hline \multirow{3}{*}{ Sentimentality } & \multirow{3}{*}{$\begin{array}{l}\text { Sexual and emotional } \\
\text { maltreatment of father }\end{array}$} & Regression & 12.41 & 2 & 6.21 & \\
\hline & & Residuals & 94.99 & 160 & 0.59 & $10.46^{\star}$ \\
\hline & & Total & 107.40 & 162 & & \\
\hline \multirow{3}{*}{ Super-optimism } & \multirow{3}{*}{$\begin{array}{c}\text { Emotional maltreatment } \\
\text { of father, } \\
\text { sexual maltreatment }\end{array}$} & Regression & 18.65 & 2 & 9.32 & \\
\hline & & Residuals & 110.95 & 160 & 0.69 & $13.44^{\star}$ \\
\hline & & Total & 129.60 & 162 & & \\
\hline \multirow{3}{*}{$\begin{array}{l}\text { Cognitive } \\
\text { indolence }\end{array}$} & \multirow{3}{*}{$\begin{array}{c}\text { Emotional } \\
\text { maltreatment of father }\end{array}$} & Regression & 23.00 & 1 & 23.00 & \\
\hline & & Residuals & 178.00 & 161 & 1.11 & $20.80^{*}$ \\
\hline & & Total & 201.00 & 162 & & \\
\hline \multirow{3}{*}{ Discontinuity } & \multirow{3}{*}{$\begin{array}{l}\text { Emotional and physical } \\
\text { maltreatment of mother, } \\
\text { Physical maltreatment } \\
\text { of father }\end{array}$} & Regression & 40.24 & 3 & 13.41 & \\
\hline & & Residuals & 146.09 & 159 & 0.92 & $14.60^{*}$ \\
\hline & & Total & 186.33 & 162 & & \\
\hline
\end{tabular}

*significant at $\alpha \leq 0.05$.

Table 6. Shows stepwise regression analysis to find out the effect of independent variable in dependent variable.

\begin{tabular}{ccccccc}
\hline Dependent variable & Independent variable & $\begin{array}{c}\text { Multi } \\
\text { correlation }\end{array}$ & $\begin{array}{c}\text { Contribution } \\
\text { percentage }\end{array}$ & $\begin{array}{c}\text { B } \\
\text { value }\end{array}$ & $\begin{array}{c}\text { Beta } \\
\text { value }\end{array}$ & t \\
\hline & $\begin{array}{c}\text { Sexual maltreatment } \\
\text { Emotional }\end{array}$ & 0.47 & 0.17 & 0.08 & 0.31 & $3.95^{*}$ \\
Mollification & $\begin{array}{c}\text { maltreatment of father } \\
\text { Physical }\end{array}$ & 0.44 & 0.20 & 0.05 & 0.57 & $3.51^{*}$ \\
& $\begin{array}{c}\text { maltreatment of father } \\
\text { matmen }\end{array}$ & 0.48 & 0.23 & -0.04 & -0.43 & $2.76^{*}$
\end{tabular}

General constant $=49.42$ 


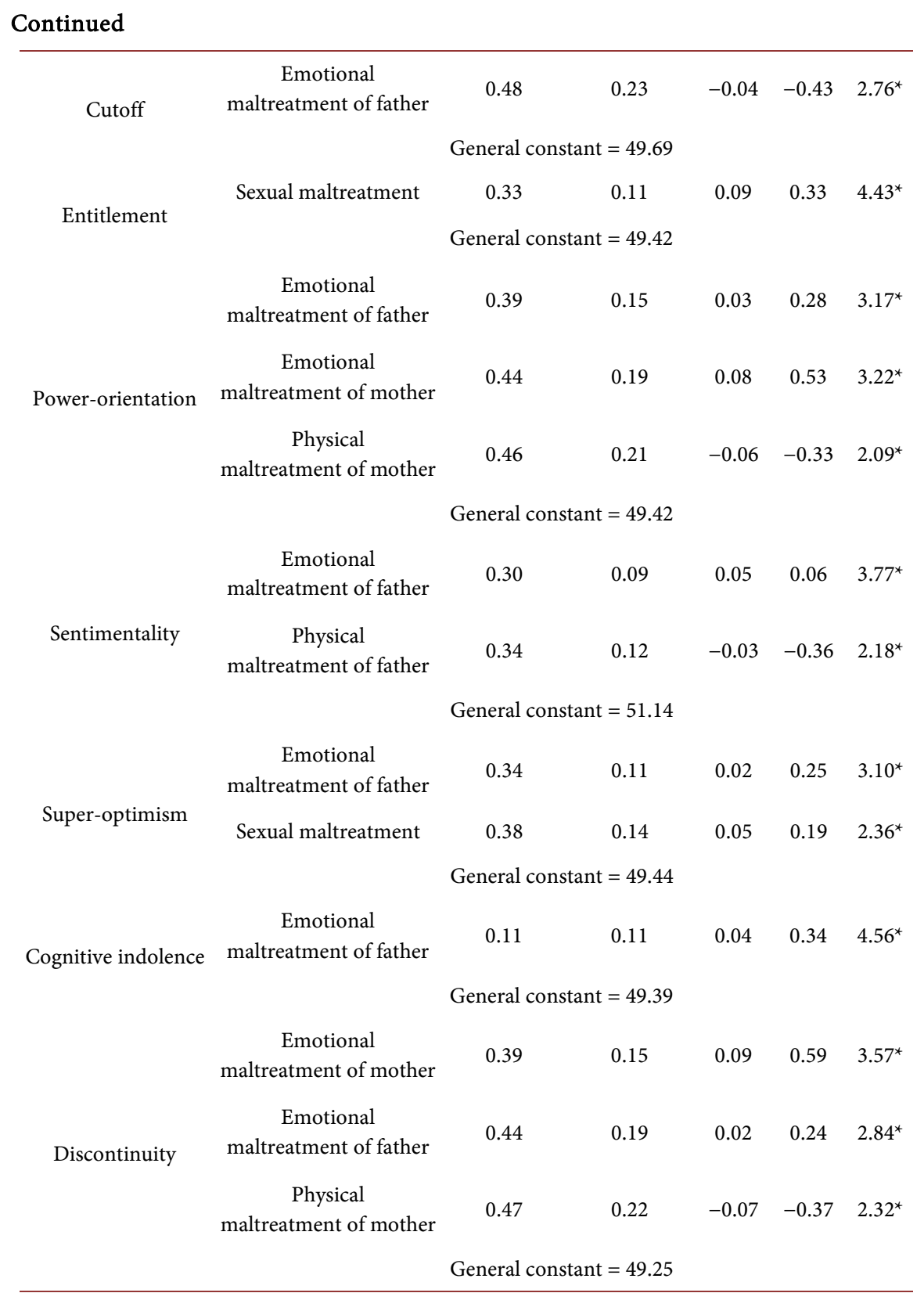

${ }^{*}$ significant at $\alpha \leq 0.05$.

4) The emotional and physical maltreatment of father and the physical maltreatment of mother can be predicted in power-orientation pattern in criminal thinking with contribution percentage $15 \%, 19 \%$ and $23 \%$ respectively, the predictive equation can be formulated as:

Power-orientation pattern $=0.028 \times$ emotional maltreatment of father + $0.58 \times$ emotional maltreatment of mother $-0.33 \times$ physical maltreatment of mother + 48.94.

5) The emotional and physical maltreatment of father can be predicted in sentimentality pattern in criminal thinking with contribution percentage $9 \%$, and $12 \%$ respectively, the predictive equation can be formulated as: 
Sentimentality pattern $=0.6 \times$ emotional maltreatment of father $-0.36 \times$ physical maltreatment of father +51.14 .

6) The emotional maltreatment of father and the sexual maltreatment can be predicted in Super-optimism pattern in criminal thinking with contribution percentage $11 \%$ and $23 \%$ respectively, the predictive equation can be formulated as:

Super-optimism pattern $=0.25 \times$ emotional maltreatment of father +0.19 $\times$ sexual maltreatment +49.44 .

7) The emotional maltreatment of father can be predicted in cognitive indolence pattern in criminal thinking with contribution percentage $11 \%$, the predictive equation can be formulated as:

Super-optimism pattern $=0.034 \times$ emotional maltreatment of father + 49.39.

8) The emotional and physical maltreatment of mother and the emotional maltreatment of father can be predicted in discontinuity pattern in criminal thinking with contribution $15 \% 22 \%$ and $19 \%$ respectively. This result can be formulated as a predictive equation in:

Discontinuity pattern $=0.59 \times$ emotional maltreatment of mother +0.24 $\times$ emotional maltreatment of father $-0.37 \times$ physical maltreatment of mother +49.25 .

\section{Discussion}

The purpose of the study was to examine the child maltreatment as predictors of criminals thinking styles, results of the study showed statistically significant differences between juveniles and normal people in favor of criminal's participants. Also, and a significant relationship between child maltreatment and criminal thinking styles. Additionally, the criminal thinking styles can be predicted from perceived father and mother maltreatment in childhood. These results originally refer to adolescents have a belief make them recognizes that parental care and control is an abuse. This leads to formation negative attitudes towards parental care, where the revenge begins to avenge during violating instructions and rebellion against laws to reach in their wishes and requirements, also adolescent consider that their desires are a basic need must be met by parents, especially the mother, where they expect a lot of compassion as a parent's duty, when their requirements and needs don't meet they consider that as bias against them which leads to thinking in entitlement way. Juveniles have attitudes towards powerorientation, so they get close from the owners of power-orientation such as groups leaders to gain position between their friend's theses exposing them sometimes to sexual abuse. Then justify to themselves that they haven't lost anything when they respond to others sexual desires.

Adolescent aggressiveness is largely associated with parent's punishment in the home, where the adolescents who are characterize by anti-social behaviours are often exposed to extreme punishment from parents, this revenge will reach to instructions and society laws in case of the adolescent interface the same atti- 
tudes because of the social context, customs, and traditions. This leads the adolescent for seeking to prove their self-concept and the daily activities, according the obstacles imposed by parents, the motives for challenge arises in different ways such as power-orientation, force using, in this context the adolescent using the criminal thinking patterns to keep a positive image about himself justifying that he was the victim or it's a way to gain power in order to express them self to, remove the non-physical obstacles, achieve the safety, make up for deprivation and humiliation without thinking about the consequences of his actions. Results of this study agree with results of study of Glenn D. Walters, 2008, Cuadra, Anna, Renu \& DiLillo, 2014, Zurbriggen, 2009, and study of Walters, 2010.

\section{Conclusions}

Juvenile delinquency is spreading in the Jordanian society. There are many centers that are working on taking care of these juveniles. Such institutes need a clearer picture of styles of thinking among the juveniles to train the supervisors and increase their knowledge and ways to deal with them. The current study conducted to examine the effects of child maltreatment as predictors of criminal thinking style among Adolescents; the study found out a statistically significant difference in exposure to maltreatment from father and mother in childhood and styles of criminal thinking between juveniles and normal people, also criminal thinking can be predicted from perceived father and mother maltreatment in childhood in Jordan.

This finding shows the danger of child maltreatment and how it affects in future and security of society; moreover how the cycle of maltreatment works with victim being prone to become a juvenile delinquent in future. These wide redlines are provided guidance for parents and non-specialist in psychology and to draw the attention of more childcare to put an end for this series of maltreatment events that prevent members of the future generations from development and moving forward.

\section{Conflicts of Interest}

The authors declare no conflicts of interest regarding the publication of this paper.

\section{References}

[1] Araji, S. and Carlson, J. (2000) Family Violence including Crimes of Jordan, Correlates, and Reception of Seriousness. Saga Journals, Violence against Women, 7, 586-621.

[2] Myers, J.E. (2009) A Short History of Child Protection in America. Family Law Quarterly, 42, 449-463.

[3] Abdul Ghafour, E. and Ibrahim, M. (1998) Maltreatment and Its Relationship to Some Psychological Disorders. Unpublished PhD Thesis, Sohag University.

[4] Benjamin, H. (2005) Childhood Maltreatment and Psychology Prospective Tests of Attachment Cognitive Vulnerability and Stress as Mediation Process. Cognitive 
Therapy and Research, 29, 645-671. https://doi.org/10.1007/s10608-005-9631-z

[5] Al-Tarawneh, N.M. (2000) Criminal Thinking of the Jordan University Students and Its Relationship to Their Gender, Level of the Study and Specialization. Unpublished Master Thesis, University of Jordan.

[6] Chaffin, M., Nonner, B. and Hill, R. (2001) Family Preservation and Family Support Programs: Child Maltreatment Outcomes across Client Risk Levels and Program Types. Child Abuse Neglect, 23, 1-35. https://doi.org/10.1016/S0145-2134(01)00275-7

[7] Binder, B.K., McFarlane, J., Nava, A., Gilroy, H. and Maddoux, J. (2013) Children in Distress: Functioning of Youngsters of Abused Women and Implications for Child Maltreatment Prevention. Child Care in Practice, 19, 237-252. https://doi.org/10.1080/13575279.2013.785935

[8] Chase, J. and Michele, S. (2007) Relationship between Criminal Thinking and Potential Child Abuse among Rural Offenders with a History of Hazardous Drinking. PhD Thesis, University of Kentucky College of Social Work, Texas Christian University, Request.

[9] Conner, S. (2008) The Relationship between Childhood Abuse and Delinquency: Examining Feminist Pathways Perspective of Female Offending. Unpublished Ph.D. Thesis, University of Texas.

[10] Samuels, J.E. (2001) An Update on the "Cycle of Violence". US Department of Justice Office of Justice Programs National Institute of Justice, 8 p.

[11] Clausen, S. (2004) Are Physically Abused Children More Likely to Become Criminals? Norsk Psykologforening, 41, 971-978.

[12] American Psychiatric Association (1994) Diagnostic and Statistical Manual of Mental Disorders. 4th Edition, Author, Washington DC.

[13] Grabrino, J., Guttman, E. and Seely, J. (1988) The Psychological Battered Child: Strategies for Identification, Assessment, and Interventions. Human Sciences Press, New York.

[14] Belsky, J. (1993) Etiology of Child: A Developmental and Ecological Analysis. Psychological Bulletin, 114, 413-434. https://doi.org/10.1037/0033-2909.114.3.413

[15] Bandura, A. (1971) Social Learning Theory. Stanford University, General Learning Press, New York.

[16] Shelly, A., McGrath, A., Abbott, N. and Kerley, R. (2011) Sexual Victimization in Childhood and the Propensity for Juvenile Delinquency and Adult Criminal Behavior: A Systematic Review. Journal of Aggression and Violent Behavior, 16, 485-492.

[17] Walters, G.D. (2010) The Psychological Inventory of Criminal Thinking Styles and Psychopath Checklist: Screening Version as Incrementally Valid Predictors of Recidivism. Law and Human Behavior, 33, 497-505.

[18] Zurbriggen, E.L. and Gobin, R.L. (2009) Childhood Emotional Abuse Predicts Late Adolescent Sexual Aggression Perpetration and Victimization. Santa Cruz, California, USA. Journal of Aggression, Maltreatment \& Trauma, 19, 204-223.

[19] Cuadra, L.E., Anna, E., Renu, T. and DiLillo, D. (2014) Child Maltreatment and Adult Criminal Behavior. Journal of Child Abuse \& Neglect, 38, 1399-1408. https://doi.org/10.1016/j.chiabu.2014.02.005 